\title{
Metabolism of dietary sulphate: absorption and excretion in humans
}

\author{
T Florin, G Neale, G R Gibson, S U Christl, J H Cummings
}

\begin{abstract}
Dietary sulphate may affect colonic pathophysiology because sulphate availability determines in part the activity of sulphate reducing bacteria in the bowel. The main product of sulphate reducing bacterial oxidative metabolism, hydrogen sulphide, is potentially toxic. Although it is generally believed that the sulphate ion is poorly absorbed, there are no available data on how much sulphate reaches the colon nor on the relative contributions from diet and endogenous sources. To resolve these questions, balance studies were performed on six healthy ileostomists and three normal subjects chosen because they did not have detectable sulphate reducing bacteria in their faeces. The subjects were fed diets which varied in sulphate content from $1.6-16.6 \mathrm{mmol} /$ day. Sulphate was measured in diets, faeces (ileal effluent in ileostomists), and urine by anion exchange chromatography with conductivity detection. Overall there was net absorption of dietary sulphate, with the absorptive capacity of the gastrointestinal tract plateauing at $5 \mathrm{mmol} /$ day in the ileostomists and exceeding $16 \mathrm{mmol} /$ day in the normal subjects. Endogenous secretion of sulphate in the upper gastrointestinal tract was from 0.96$2.6 \mathrm{mmol} / \mathrm{day}$. The dietary contribution to the colonic sulphate pool ranged up to $9 \mathrm{mmol}$ day, there being linear identity between diet and upper gastrointestinal losses for intakes above $7 \mathrm{mmol} / \mathrm{day}$. Faecal losses of sulphate were trivial $(<0.5 \mathrm{mmol} / \mathrm{day})$ in the normal subjects at all doses. It is concluded that diet and intestinal absorption are the principal factors affecting the amounts of sulphate reaching the colon. Endogenous secretion of sulphate by colonic mucosa may also be important in determining amounts of sulphate in the colon.
\end{abstract}

Sulphate reduction does not occur in mammalian cells. It does occur in bacteria, and in particular, in sulphate reducing bacteria, which can couple oxidative phosphorylation with reduction of sulphate (replacing oxygen in conventional aerobic respiration) to produce hydrogen sulphide.' Sulphate reducing bacteria genera, such as Desulfovibrio, Desulfomonas, and Desulfobacter, are found in the human colon. ${ }^{23}$ Interest in them arises from their role in colonic fermentation and in the possibility that hydrogen sulphide might be pathogenic to the bowel mucosa. ${ }^{4}$ Sulphate reducing bacteria oxidise a range of readily available organic compounds in the colon (short chain fatty acids, hydrogen, succinate, lactate, ethanol, pyruvate) and are likely to be growth limited not by substrate, but by availability of the terminal electron acceptor, sulphate. Large numbers of sulphate reducing bacteria are found in the colon especially in people who do not excrete methane in their breath, ${ }^{5}$ and experiments in vitro ${ }^{6}$ and in vivo have suggested that these bacteria might outgrow methanogenic bacteria when there is an adequate supply of sulphate.

In order to understand more fully the role of sulphate in determining sulphate reducing bacteria carriage and activity, it is important to know the amount of sulphate available in the colon and the relative contributions from diet and endogenous secretions. There are, however, few available data on the sulphate content of foods - for example, sulphate is not mentioned in McCance and Widdowson's The Composition of Foods $^{8}$ - and the amount of sulphate secreted by the intestine is not known.

Sulphate is believed to be poorly absorbed by the human gastrointestinal tract. ${ }^{910}$ Hence the basis for its use as an osmotic laxative, and as a non-absorbable anion in absorption studies. ${ }^{11} 12$ Sulphate excretion in urine has been ascribed entirely to the oxidation of sulphur in sulphur amino acids. ${ }^{13}$ On the other hand, animal studies indicate that appreciable absorption of sulphate is possible by the upper gastrointestinal tract of a variety of monogastric mammals. ${ }^{1+16}$ Also, in humans, tracer doses of radioactive sulphate given by mouth are well absorbed, ${ }^{17}{ }^{18}$ with more than $80 \%$ of radioactivity being recovered in urine over 24 hours. ${ }^{18}$

We have therefore measured the amount of sulphate passing into the colon from the upper gastrointestinal tract from dietary and endogenous sources by feeding ileostomy subjects diets containing variable amounts of sulphate and measuring sulphate excretion in ileostomy fluid and urine. Sulphate in cooked food is mainly in the free anionic form ${ }^{19}$ On the other hand, sulphate from intestinal secretions is esterified with glycoproteins (mainly mucin) and to a lesser extent with steroids and glycolipids. ${ }^{20}$ Because there is little sulphatase activity in the mucosa of the gastrointestinal tract, ${ }^{21}$ the free sulphate in ileal effluent is likely to be of dietary origin, whereas bound sulphate is largely endogenous. Sulphate losses in ileal effluent are assumed to be the same as the sulphate which reaches the caecum in the intact gut.

In a further balance experiment to assess the role of the colon in sulphate absorption we measured sulphate intakes against losses in faeces and urine from a group of normal subjects. The subjects in this group, who were fed a low sulphate diet supplemented with oral sodium sulphate during a test period, were selected by the criterion of having no detectable sulphate reducing bacteria in their faeces. 
TABLE III Ileostomy effluent weight (g/day), and sulphate (mmol/day) in diets, ileostomy effluent, and urine of six healthy ileostomists

\begin{tabular}{|c|c|c|c|c|c|c|}
\hline $\begin{array}{l}\mathrm{Diet}^{\star} \\
\mathrm{SO}_{+}\end{array}$ & $\begin{array}{l}1 \\
2 \cdot 1\end{array}$ & $\begin{array}{l}2 \\
5 \cdot 2\end{array}$ & $\begin{array}{l}3 \\
6.9\end{array}$ & $\begin{array}{l}4 \\
11 \cdot 4\end{array}$ & $\begin{array}{l}5 \\
12 \cdot 0\end{array}$ & $\begin{array}{l}6 \\
15 \cdot 8\end{array}$ \\
\hline $\begin{array}{l}\text { Ileostomy effluent } \\
\text { Wet weight } \\
\text { (SE) } \\
\text { Dry weight } \\
\text { (SE) } \\
\text { Total } \mathrm{SO}_{4} \\
\text { (SE) } \\
\text { Free } \mathrm{SO}_{4} \\
\text { (SE) } \\
\text { Bound } \mathrm{SO}_{4} \\
\text { (SED†) } \\
\text { Urine SO } \\
4\end{array}$ & $\begin{array}{l}849 \\
(56) \\
59 \\
(2) \\
1 \cdot 3 \\
(0 \cdot 1) \\
0 \cdot 29 \\
(0 \cdot 03) \\
0 \cdot 96 \\
(0 \cdot 14) \\
16 \cdot 8 \\
(1 \cdot 4)\end{array}$ & $\begin{array}{l}627 \\
(37) \\
58 \\
(3) \\
2 \cdot 1 \\
(0 \cdot 2) \\
0 \cdot 99 \\
(0 \cdot 11) \\
1 \cdot 1 \\
(0 \cdot 3) \\
19.4 \\
(1 \cdot 4)\end{array}$ & $\begin{array}{l}1136 \\
(54) \\
87 \\
(3) \\
3 \cdot 3 \\
(0 \cdot 2) \\
1 \cdot 7 \\
(0 \cdot 3) \\
1 \cdot 6 \\
(0 \cdot 5) \\
22 \cdot 0 \\
(0 \cdot 6)\end{array}$ & $\begin{array}{l}1147 \\
(88) \\
102 \\
(4) \\
6 \cdot 5 \\
(0 \cdot 4) \\
4 \cdot 3 \\
(0 \cdot 2) \\
2 \cdot 2 \\
(0 \cdot 6) \\
21 \cdot 2 \\
(0 \cdot 4)\end{array}$ & $\begin{array}{l}673 \\
(40) \\
61 \\
(2) \\
7 \cdot 1 \\
(0 \cdot 2) \\
5 \cdot 5 \\
(0 \cdot 2) \\
1 \cdot 6 \\
(0 \cdot 4) \\
22 \cdot 0 \\
(0 \cdot 8)\end{array}$ & $\begin{array}{l}1435 \\
(74) \\
121 \\
(8) \\
10 \cdot 8 \\
(0 \cdot 7) \\
8 \cdot 2 \\
(0 \cdot 6) \\
2 \cdot 6 \\
(1 \cdot 3) \\
20 \cdot 0 \\
(2 \cdot 0)\end{array}$ \\
\hline
\end{tabular}

^For details of diets and composition see Tables I and II. tStandard error difference of means.

according to protocol was $94 \%$ and $92 \%$ respectively (two subjects). Recovery of sulphate from samples spiked with inorganic sulphate and then treated with acid hydrolysis was $90 \%$; recovery of ester sulphate added as chondroitin sulphate to urine and effluent, and stored according to protocol was $100 \%$ and $91 \%$ respectively (two subjects).

\section{FAECAL BALANCE STUDY}

\section{Protocol}

Three healthy volunteers with normal gastrointestinal tracts and no detectable sulphate reducing bacteria in their faeces were fed a low sulphate diet ( $1.6 \mathrm{mmol} /$ day) for 30 days. From days 11 to 20 , the diets were supplemented with sodium sulphate ( $15 \mathrm{mmol} /$ day) in three divided doses. From days 21 to 30 , two subjects returned to the low sulphate diet but the other subject's diet was supplemented with 1.51 beer (which contained $5.0 \mathrm{mmol}$ sulphate). Total urine and faecal collections were made for the last two and five days respectively of each period. Faeces were quickly frozen at $-20^{\circ} \mathrm{C}$ and urine was stored in the manner described above.

\section{Bacteriology}

Total viable counts were measured in anaerobic dilution shake series. ${ }^{3-5}$ The minimum detectable concentration was $10^{2}$ sulphate reducing bacteria/g wet weight of faeces. Sulphate reducing bacteria activity was assessed by measuring rates ${ }^{35} \mathrm{~S}$-sulphate reduction to ${ }^{35} \mathrm{~S}$-sulphide. ${ }^{23} \mathrm{~A}$ value of $10 \mathrm{nmol} / \mathrm{g} / \mathrm{h}$ or greater was taken to indicate sulphate reducing bacteria activity.

\section{REAGENTS AND ETHICS}

All chemicals were of Aristar grade purchased from BDH or Sigma, and all water was deionised $(>20 \mathrm{M} \Omega$ ) and filtered ( 0.2 micron).

The study was approved by the MRC Dunn Nutrition Unit Ethical Committee.

\section{Results}

\section{ILEOSTOMY STUDY}

The sulphate content of the diets varied between $2 \cdot 1 \mathrm{mmol} /$ day and $15 \cdot 8 \mathrm{mmol} /$ day (Table III). There was no significant bound sulphate in the cooked dietary samples.

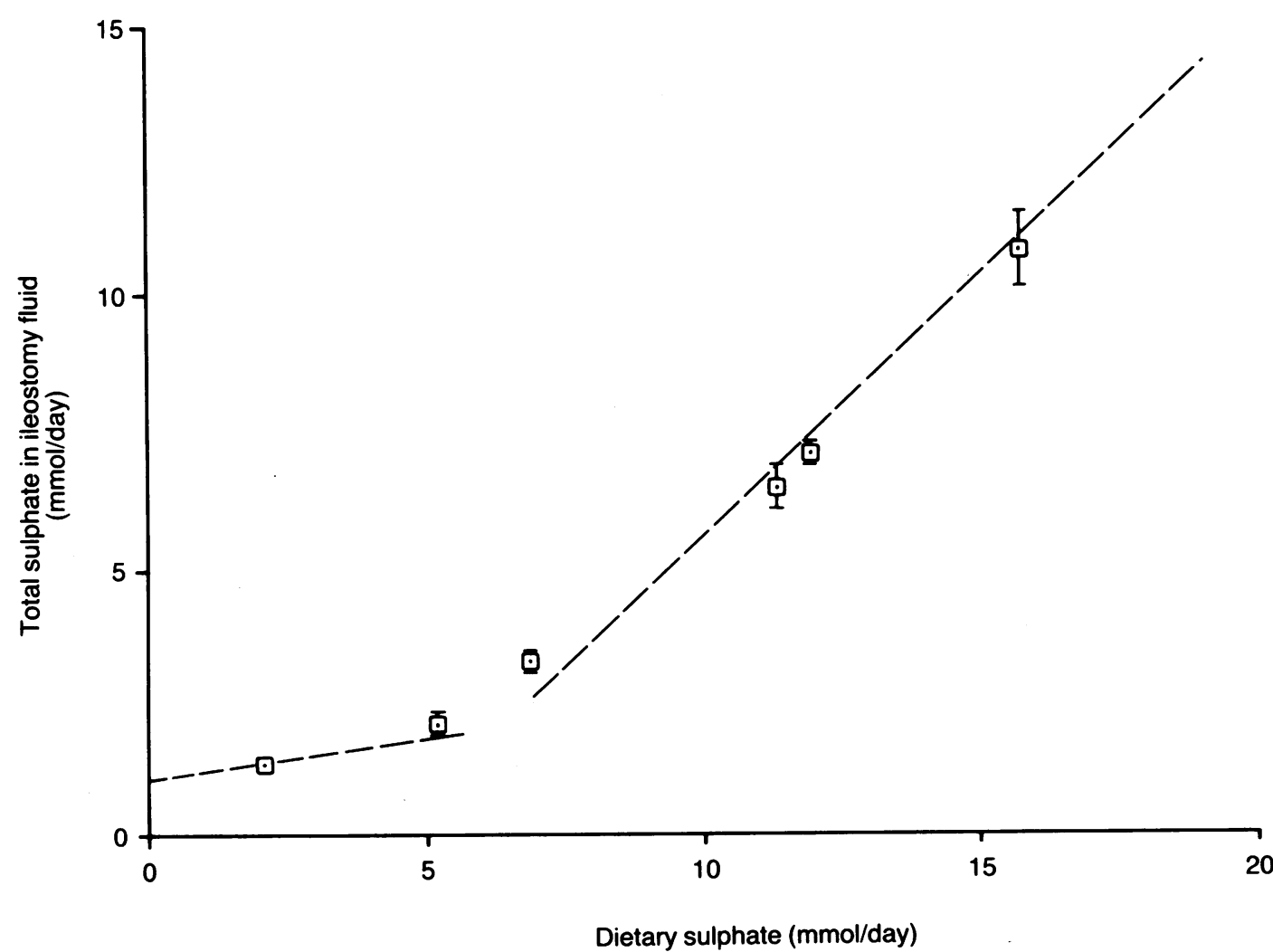

Figure 1: Total sulphate excretion in ileostomy fluid $\mathrm{v}$ dietary sulphate (mmol/day). For intakes above 7 mmol/day there was a linear identity between ileal excretion and intake of sulphate. Linear extrapolation at low intakes suggests a net secretion of sulphate into ileostomy fluid for dietary sulphate less than 1 mmol/day. Bars show standard error of the mean. 


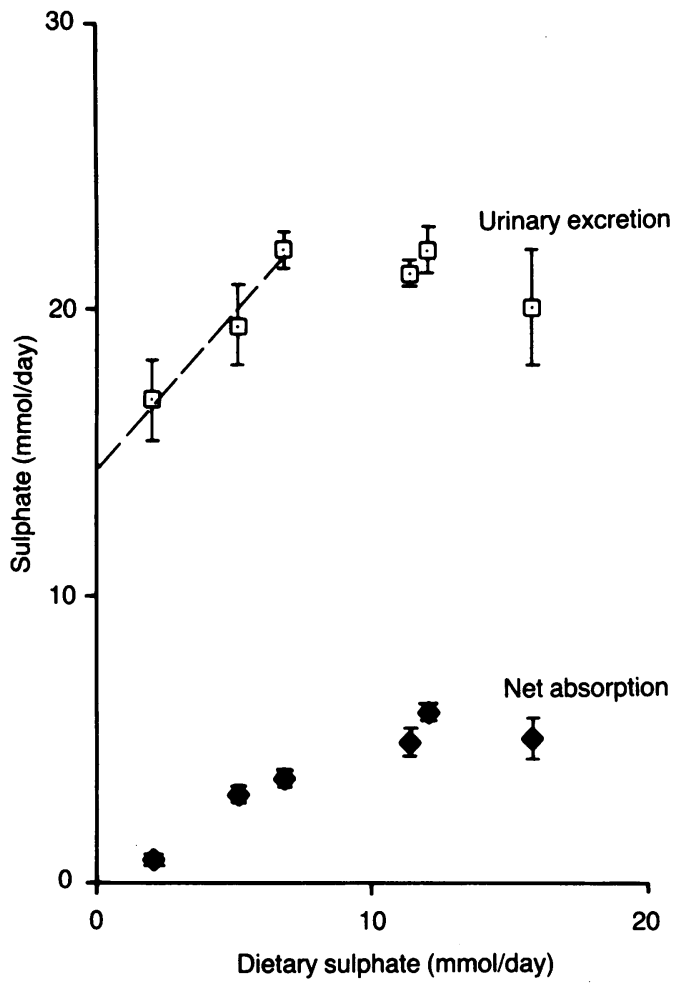

Figure 2: Mean urinary excretion of sulphate and net intestinal sulphate absorption (dietary - total ileal sulphate) $\mathrm{v}$ dietary sulphate in the ileostomists. Mean urinary excretion of sulphate correlated with intestinal absorption. (Linear regression $r=0.82, p<0.05)$. The dotted line indicates the linear extrapolation through data points for dietary sulphate $<7.5 \mathrm{mmol} / d a y$ through to zero sulphate intake. The intercept of urinary sulphate at zero sulphate intake, $14.8 \mathrm{mmol} / d a y$, represents sulphate derived from oxidation of $S$-amino acids. Bars show standard error of the mean.

Mean (SE) recovery of free and total sulphate in ileal effluent was $0.29(0.02)$ and $1.3(0.11)$ $\mathrm{mmol} /$ day respectively for the lowest sulphate diet, increasing to $8.2(0.5)$ and $10.8(0.7) \mathrm{mmol} /$ day for the highest sulphate diet (Table III). Total sulphate excretion in ileostomy fluid was directly proportional to ingested sulphate for intakes above $7 \mathrm{mmol} /$ day and there was a net loss of sulphate into ileostomy fluid for dietary intakes of less than about $1 \mathrm{mmol} /$ day (Fig 1). Excretion of bound sulphate increased slightly with increasing dietary intake, from $0.96(0.14)$ to $2 \cdot 6(1 \cdot 3) \mathrm{mmol} /$ day (Table III); (linear regression analysis $r=0.90$, slope $=0.12, p=0.013$ ). This correlation persisted when multiple regression analysis was used to distinguish the different roles of dietary sulphate and ileal dry weight in determining bound sulphate: ileal bound sulphate $(\mathrm{mmol} /$ day $)=0.016 \times$ ileal dry weight (g/day) $+0.06 \times$ dietary sulphate (mmol/day) $+0.17 \mathrm{mmol} /$ day, $\mathrm{r}=0.99, \mathrm{p}=0.000$.

-Mean (SED) net intestinal absorption (dietary - total ileal sulphate) was $0.85(0.22) \mathrm{mmol} / \mathrm{day}$ for the lowest sulphate intake, increased to 5.0 $(1.5) \mathrm{mmol} /$ day for higher intakes, and plateaued at sulphate intakes above $7 \mathrm{mmol} /$ day. This correlated with excretion of urinary sulphate which also plateaued at intakes above $7 \mathrm{mmol}$ day (Fig 2). The intercept of urinary sulphate at zero sulphate intake, $14.8 \mathrm{mmol} /$ day (Fig 2), represents sulphate derived from oxidation of S-amino acids. This is close to but slightly less than the mean amino acid sulphur in the diets,
18.5 (0.76) $\mathrm{mmol} /$ day, calculated from The Composition of Foods $^{8}$ values (Table II).

Although there was a tendency for total urine sulphate to be greater than free urine sulphate, significant bound sulphate was not detected in ileostomy urine samples.

Total excretion of sulphate in ileostomy fluid and urine correlated linearly with intake of sulphate (Fig 3). (The excretion value at dietary sulphate $7 \cdot 2 \mathrm{mmol} /$ day corresponds to the diet with the highest calculated S-amino acid; Table II).

FAECAL BALANCE STUDY

Sulphate reducing bacteria were not detected during the collection periods; nor was evidence of sulphate reducing bacteria activity found in any of the faeces, even during sulphate feeding. The sulphate content of the unsupplemented diet was $1.6 \mathrm{mmol} /$ day, and for the supplemented diets $6.6 \mathrm{mmol} /$ day and $16.6 \mathrm{mmol} /$ day (Table IV). The calculated mean S-amino acid content of the diet was $23.4(1.5) \mathrm{mmol} /$ day, based on The Composition of Foods. ${ }^{8}$ Mean faecal weight which was 94 (12) g/day, increased with corresponding increasing sulphate intakes (80, 95 , and $112 \mathrm{~g} /$ day), but this was not significant $(\mathrm{p}>0 \cdot 2)$.

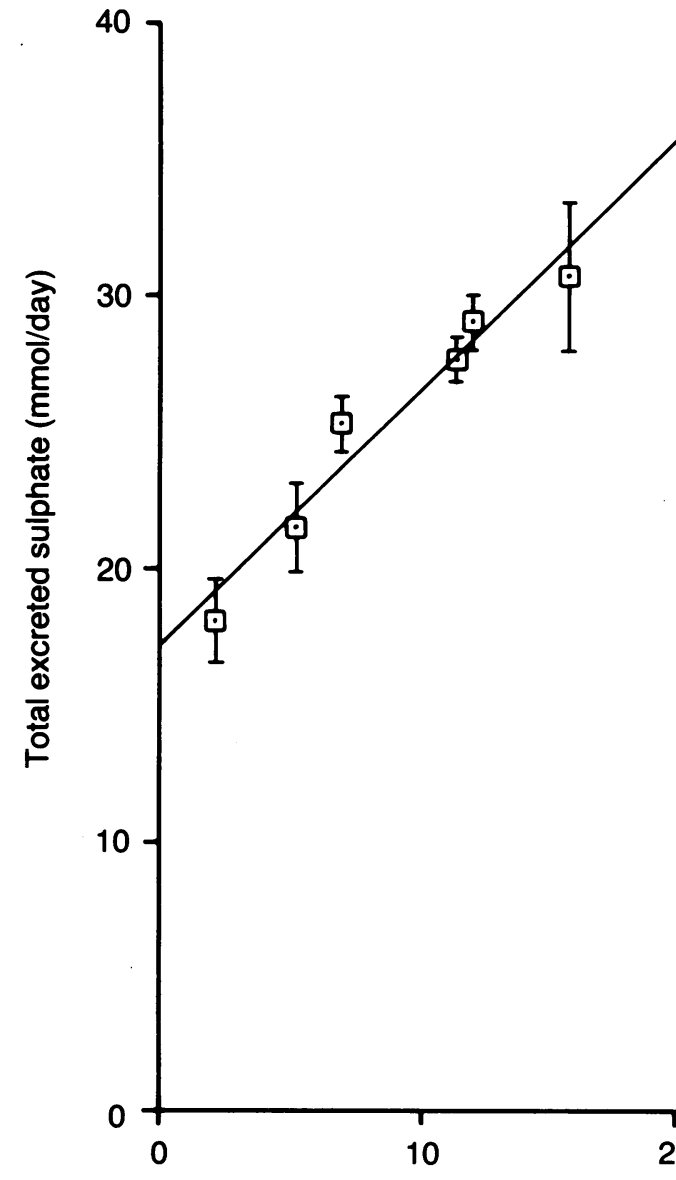

Dietary sulphate (mmol/day)

Figure 3: Mean sulphate excretion in ileostomy fluid and urine $\mathrm{v}$ intake for six healthy ileostomists. (Linear regression $r=0.98$, slope $=1 \cdot 12, p<0.001)$. The excretion value at dietary sulphate of $7 \cdot 2 \mathrm{mmol} / \mathrm{day}$ corresponds to the diet with the highest calculated S-amino acid (Table II). Bars show standard error of the mean. 


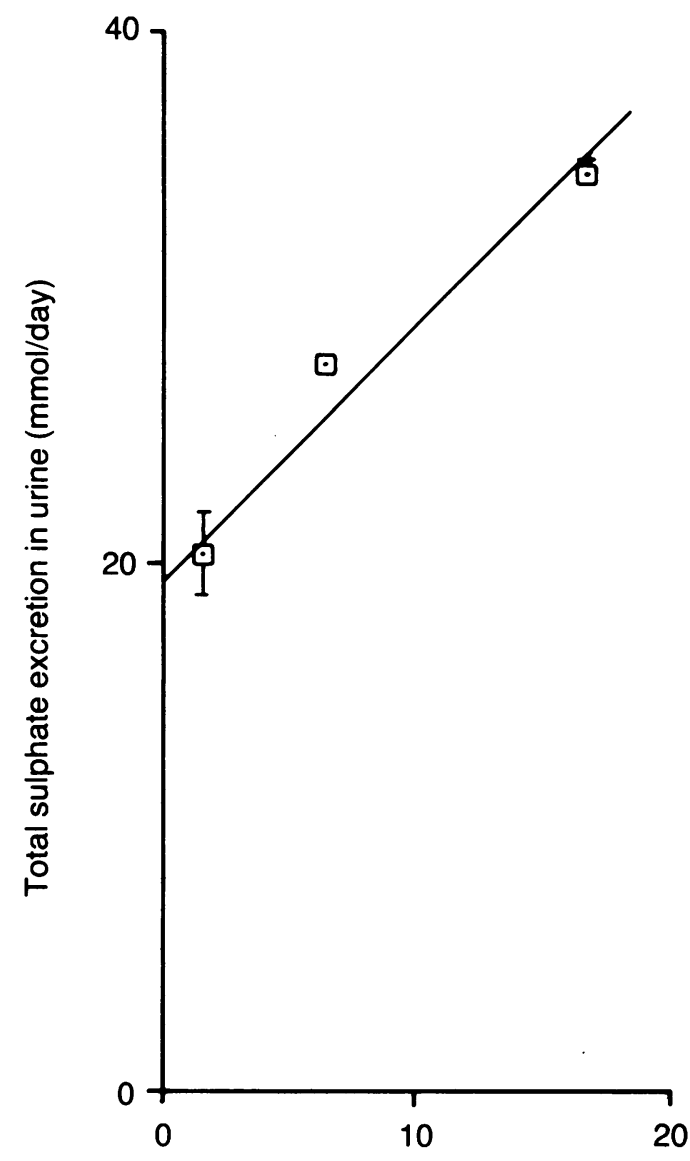

Dietary sulphate (mmol/day)

Figure 4: Total urinary sulphate $\mathrm{v}$ dietary sulphate for three normal volunteers. (Linear regression $r=0.94$, slope $=0.97$, $p<0.02)$. The intercept of urinary sulphate at zero sulphate intake, $19.4 \mathrm{mmol} / \mathrm{day}$, represents sulphate derived from oxidation of dietary S-amino acids. Bars show standard error of the mean.

The sulphate content of faeces from the sulphate reducing bacteria-negative volunteers was uniformly low for all diets with mean total faecal sulphate excretion being $0.26(0.06)$ $\mathrm{mmol} /$ day, mean free faecal sulphate $0 \cdot 10(0.04)$ $\mathrm{mmol} /$ day, and mean bound sulphate $0 \cdot 16(0 \cdot 10)$ $\mathrm{mmol} /$ day. There was a small increase in faecal sulphate with increasing dietary sulphate (Table IV), which was not significant.

Urinary excretion of sulphate correlated linearly with dietary sulphate, linear regression $r=0.94, p<0.02$ (Fig 4); 97\% of dietary sulphate was excreted in urine. The intercept of urinary

TABLE IV Sulphate (mmol/day) in diets, faeces, and urine from three normal volunteers

\begin{tabular}{|c|c|c|c|}
\hline $\begin{array}{l}\mathrm{Diet} \\
\mathrm{SO}_{4}\end{array}$ & $\begin{array}{l}1 \\
1 \cdot 6\end{array}$ & $\begin{array}{l}2 \\
6 \cdot 6\end{array}$ & $\begin{array}{l}3 \\
16 \cdot 6\end{array}$ \\
\hline \multicolumn{4}{|l|}{ Faeces: } \\
\hline $\begin{array}{l}\text { Total } \mathrm{SO}_{4} \\
\text { (SE) }\end{array}$ & $\begin{array}{l}0 \cdot 18 \\
(0.05)\end{array}$ & $\begin{array}{l}0.30 \\
(0)\end{array}$ & $\begin{array}{l}0.35 \\
(0.13)\end{array}$ \\
\hline Free $\mathrm{SO}_{4}$ & 0.02 & $0 \cdot 19$ & 0.17 \\
\hline Bound $\mathrm{SO}_{4}$ & $\begin{array}{l}0 \cdot 16 \\
(0 \cdot 06)\end{array}$ & $\begin{array}{l}0 \cdot 11 \\
(0)\end{array}$ & $\begin{array}{l}(0.08) \\
0 \cdot 18 \\
(0.21)\end{array}$ \\
\hline \multicolumn{4}{|l|}{ Urine: } \\
\hline $\begin{array}{l}\text { Total } \mathrm{SO}_{4} \\
\text { (SE) }\end{array}$ & $\begin{array}{l}20 \cdot 3 \\
(1.6)\end{array}$ & $\begin{array}{l}27 \cdot 5 \\
(0)\end{array}$ & $\begin{array}{l}3+\cdot 8 \\
(0 \cdot 4)\end{array}$ \\
\hline Free $\mathrm{SO}_{4}$ & $17 \cdot 5$ & 23.9 & 31.7 \\
\hline (SE) & $(2 \cdot 0)$ & $(0)$ & $(1 \cdot 0)$ \\
\hline $\begin{array}{l}\text { Bound } \mathrm{SO}_{4} \\
\left(\mathrm{SED}^{\star}\right)\end{array}$ & $\begin{array}{l}2.8 \\
(3 \cdot 6)\end{array}$ & $\begin{array}{l}3 \cdot 6 \\
(0)\end{array}$ & $\begin{array}{l}3 \cdot 1 \\
(1 \cdot 4)\end{array}$ \\
\hline
\end{tabular}

^Standard error difference of means. sulphate at zero dietary sulphate was $19 \cdot 4 \mathrm{mmol}$ day (Fig 4). There was appreciable bound sulphate in the urine (Table IV). Mean total urinary sulphate for all diets, $25 \cdot 7(2 \cdot 4) \mathrm{mmol} /$ day, was significantly greater than mean free urinary sulphate, $22.7(2.4) \mathrm{mmol} /$ day (paired $t$ test, $\mathrm{p}=0.002$ ), so that bound sulphate accounted for $12 \%$ of total urinary sulphate in the normal volunteer group.

\section{Discussion}

\section{SULPHATE IN FOOD}

Intakes of dietary sulphate varied over a $7 \cdot 5$-fold range from $2 \cdot 1-15 \cdot 8 \mathrm{mmol} /$ day. Although the ileostomy diets were experimental, they comprised normal food constituents and had nutritional contents broadly similar to those of typical British diets. ${ }^{24}$ There are no available data for sulphate intakes in the population, but from the present studies it is probably within the range between 1.5 and $16 \mathrm{mmol} /$ day.

Foods high in sulphate include commercial breads, dried fruits and vegetables, nuts, fermented beverages, and brassica vegetables. ${ }^{19}$ Much of this sulphate is added during processing. Ferrous, calcium, and ammonium sulphates are permitted additives in bread manufacture (Bread $\mathcal{E}$ Flour Regulations ${ }^{25}$ ). Home baked bread using commercially available flour does not have a high sulphate content. Calcium sulphate is used to remove temporary hardness and lower $\mathrm{pH}$ in some beer recipes ${ }^{26}$ and ferrous sulphate is added to East Anglian water to precipitate organic matter in the cleanup process. Addition of sulphite or disulphite to fruit or vegetables as a preservative, or to some beverages to control fermentation, is another source of dietary sulphate, because sulphate is a common impurity in sulphite (up to $15 \%$, unpublished results) and some sulphite is oxidised to sulphate during storage and cooking. ${ }^{27-29}$ Some glucosinolate containing foods, such as cabbage, are naturally rich in sulphate, although the amounts may be influenced by fertilisers. ${ }^{30}$

SULPHATE ABSORPTION AND URINARY EXCRETION

These experiments show net absorption of dietary sulphate and its excretion in urine over 24 hours in human subjects fed a range of sulphate in diets broadly in keeping with British eating habits. Maximum net absorption by the upper gastrointestinal tract plateaued at $5 \mathrm{mmol} /$ day with dietary intakes of $7 \mathrm{mmol} /$ day and above. If it is assumed that upper gastrointestinal tract absorption of sulphate in the normal volunteer group is the same as in the ileostomy group, and that there was negligible metabolism of sulphate in the colon because of the absence of sulphate reducing bacteria, then net colonic absorption of sulphate accounted for about $10 \mathrm{mmol} /$ day during the period of high sulphate $(16.6 \mathrm{mmol} /$ day) intake. This conclusion is in agreement with Ruppin et al, ,1 who reported to their surprise, colonic sulphate absorption, in a study of short chain fatty acid absorption in the human colon where they were using sulphate as a poorly absorbed anion control. 
These data do not give evidence about the mechanism for sulphate absorption, but are consistent with a low capacity, high affinity active transport in the mucosa. In the present studies sulphate absorption paralleled sulphate losses in urine, with absorbed sulphate being largely excreted within 24 hours in urine. In vitro studies of small intestine indicate a sodium dependent active transport of sulphate which is maximal in the ileum of the rat, ${ }^{15233}$ the rabbit, and the hamster, ${ }^{33}$ and the rapid clearance is consistent with free glomerular filtration and low capacity renal tubular resorption of sulphate, which has been documented in subjects given intravenous infusions of sodium sulphate. ${ }^{34}$ Another report of the excretion of $389 \mathrm{mmol}$ of intravenous sodium sulphate in urine over 24 hours attests to the rapidity of renal sulphate excretion. ${ }^{35}$ Incomplete 24 hour recovery $(86 \%)$ of a tiny oral dose of radioactive sulphate ${ }^{18}$ probably reflects exchange of radiolabelled sulphate with a slow-turnover body pool of sulphate - for example, chondroitin sulphate or mucin - rather than delayed absorption or excretion.

Maximum intestinal sulphate absorptive capacity was not reached in our normal volunteer group. In an unpublished study in which a healthy volunteer was given a massive isosmotic dose of sodium sulphate by mouth $(380 \mathrm{mmol}$ over four hours), the urine contained $52 \mathrm{mmol}$ of sulphate in excess of estimated protein derived sulphate over two days (unpublished results). This represents nearly $14 \%$ of the oral dose; the effective bowel clearance which also occurred testifies to the laxative properties of the remaining $86 \%$. On the other hand, Fordtran's group ${ }^{36}$ concluded that there was insignificant urinary excretion of sulphate in volunteers who ingested $341 \mathrm{mmol}$ of sulphate in an electrolyte lavage solution. The mean sulphate excretion in urine, however, was higher during their lavage period and this may have proved significant if a paired Student's $t$ test had been used for comparison rather than an unpaired test. A similar finding to our study was noted by Cochetto and Levy ${ }^{37}$ who gave 10 healthy volunteers $60 \mathrm{mmol}$ of sulphate in three divided doses over 24 hours. They calculated that the mean excess sulphate excreted in urine over three days was $37 \mathrm{mmol}$ or nearly $62 \%$ of the oral dose. (The prolonged excretion of urinary sulphate after ingestion of laxative sulphate doses presumably reflects delayed absorption of sulphate from sulphate rich fluid pooled in the bowel.)

The sulphate derived from oxidation of S-amino acids in the diets is calculated to be (mean (SE)) 18.5 (0.76) and 23.4 (1.5) mmol/day in the ileostomy and faecal balance studies respectively. The corresponding values of 14.8 and $19.4 \mathrm{mmol} /$ day read from the intercepts of urinary sulphate at zero sulphate intake are 17$20 \%$ lower than the values calculated from the food composition tables. ${ }^{8}$ This difference is within the range of error due to losses of urinary sulphate in storage (discussed in the methods section) or variations in actual S-amino acid and that calculated from food composition tables, as well as being compatible with unquantified losses of sulphate and S-amino acid shed from skin, or S-amino acid excreted in ileostomy fluid $^{38}$ and faeces. Dietary sulphate in the ileostomy subjects accounted for between 5\% and $20 \%$ of urinary sulphate, and in the normal volunteer group where unabsorbed sulphate in the upper gastrointestinal tract was salvaged by colonic absorption, it accounted for up to $42 \%$ of urinary sulphate, It is therefore incorrect to ascribe urinary sulphate solely to oxidation of sulphur amino acids ${ }^{13}$ in subjects fed British diets.

Appreciable bound sulphate was not found in the urine of ileostomy subjects. By contrast, $12 \%$ of urinary sulphate was in the bound form in the normal volunteer group. Most of the bound sulphates in urine are esters of phenol, indole, and p-cresol, ${ }^{39}$ which are derived from bacterial degradation of aromatic amino acids ${ }^{20}$ in the gut. Production of phenolic compounds is likely to be favoured in the lumen of the left colon. ${ }^{+0}$ These compounds are then sulphated by the colonic mucosa $^{41}$ which, like mucosa throughout the gastrointestinal tract ${ }^{20}$ and the liver, has a substantial capacity for sulphation of phenolic compounds. As ileostomy subjects have greatly reduced numbers of gut bacteria, it is perhaps not surprising that their urinary sulphate is mainly in the free form.

Is the ileostomy subject a good model for the absorption of sulphate by the upper gastrointestinal tract of normal subjects? Binder and Ptak $^{42}$ reported that people with untreated colitis might have impaired handling of sodium and water in the small intestine. However, although five of six of our ileostomy subjects had previously suffered from ulcerative colitis, their colectomies had been curative. One subject, who had his colectomy for sporadic bowel cancer, had ileal sulphate losses which were well within the range of values for the group. For sulphate intakes of $6.9,11.4$, and $15.8 \mathrm{mmol} /$ day respectively, his ileal losses were $3 \cdot 4,7 \cdot 2$, and $11.5 \mathrm{mmol} /$ day. So reduced absorption of sulphate in the upper gastrointestinal tract of the ileostomy subjects is unlikely. In fact because these people have no colon to salvage unabsorbed electrolytes, compensatory changes, ${ }^{43}$ such as increased serum aldosterone, ${ }^{+4}$ might result in increased sulphate absorption by the upper gastrointestinal tracts of this group. Therefore the absorptive role of the colon might be underestimated in our calculations.

Another possible fate for sulphate in the colon which merits consideration is that it is first reduced to hydrogen sulphide by bacteria, then absorbed and reoxidised to sulphate. Although there are no quantitative data on hydrogen sulphide production in the bowel or its absorption by intestinal mucosa in humans, this gaseous compound is very water soluble $\left(2000 \mathrm{ml} / \mathrm{l}\right.$ water at $37^{\circ} \mathrm{C}$, compared with solubilities of $18 \mathrm{ml} / \mathrm{l}$ water for hydrogen, and $570 \mathrm{ml} / \mathrm{l}$ water for carbon dioxide) and is mainly in a nonionic form at faecal $\mathrm{pH}\left(\mathrm{pK}_{\mathrm{al}}=7 \cdot 04\right)$. ${ }^{45}$ Therefore, if not consumed by chemical or enzymatic reactions in the gut lumen, hydrogen sulphide is likely to be readily absorbed. This has been shown in whole animal experiments, for canine large and small intestine ${ }^{46}$ and ovine rumen and duodenum. ${ }^{47}$ Absorbed hydrogen sulphide is 
readily oxidised to sulphate, although there is controversy about the sites and mechanisms of its oxidation. . $^{4-52}$

It is unlikely that an appreciable reduction of sulphate occurred in our subjects, who had no sulphate reducing activity in vitro. The sulphur requirement of faecal bacteria if sulphate reducing bacteria are not present is not more than 1-2 mmol/day. Most of this requirement would be met by cysteine and methionine from protein degradation. Bacterial assimilation of sulphate to produce hydrogen sulphide for sulphur needs is a process requiring adenosine triphosphate whose pathway is repressed when bacteria are grown with cysteine..$^{534}$. Making the unlikely assumption that non-sulphate reducing bacterial sulphur needs are all met by sulphate, and assuming an average bacterial faecal dry mass of $14.7 \mathrm{~g}$, and bacterial nitrogen content of $0.88 \mathrm{~g}$ (calculated from Stephen and Cummings, ${ }^{55}$ ) and a nitrogen to sulphur ratio of 16 , then the sulphate assimilated for bacterial sulphur needs would amount to only $1.7 \mathrm{mmol} /$ day. Moreover, the sulphate requirement for bacterial sulphur would be considerably less in ileostomy subjects, whose gut bacterial load is many orders of magnitude smaller than that of normal subjects.

\section{ENDOGENOUS SULPHATE SECRETION}

In this study we were able to estimate for the first time net endogenous sulphate secretion by the human upper gastrointestinal tract, 0.96$2.6 \mathrm{mmol} /$ day. Some of the bound sulphate is esters of steroids, phenols, glycoproteins, chondroitin, and glycolipids, but most is probably in mucin. By assuming all bound sulphate to be from mucin and $3.4 \%$ sulphate in the carbohydrate portion of small intestinal mucin,${ }^{56}$ then the daily carbohydrate contribution from mucin secretion by the upper gastrointestinal tract is estimated to be $2 \cdot 7-7 \cdot 3 \mathrm{~g} /$ day in our subjects. This calculation is in approximate agreement with estimations of mucin secretion based on measurements of hexosamines in ileostomy fluid $^{57}(3.4 \mathrm{~g} /$ day) or of total carbohydrate in the ileostomy fluid of subjects on a polysaccharide free $\operatorname{diet}^{58}(2 \cdot 3 \mathrm{~g} /$ day $)$.

Extrapolation of bound sulphate losses into ileostomy fluid is consistent with obligatory synthesis of sulphate at very low intakes. At higher sulphate intakes there is a small but significant increase in ileal bound sulphate $(0.06 \mathrm{mmol} / \mathrm{mmol}$ ingested sulphate). From the present data it can be inferred that this might be due to both increased sulphation of secreted substances and, increased endogenous secretion at high sulphate intakes. The multiple regression equation, however, which relates total ileal bound sulphate to daily dietary sulphate and weight of ileal effluent, may exaggerate the latter influence if there is a systemic error in sulphate measurement, because bound sulphate $(\mathrm{mmol} /$ day) has been derived from the product of ileal dry weight (g) and ileal bound sulphate $(\mathrm{mmol} / \mathrm{g})$.

The contribution of endogenous sulphate to the total colonic sulphate pool seems to be small. It is, however, underestimated in this study, because first and foremost the study does not quantify the amount of sulphate from colonic mucin. This may be considerable as radiographic tracer methods and histology in animals ${ }^{59}$ and humans ${ }^{6061}$ indicate that colonic mucin is more highly sulphated than small intestinal and gastric mucin. Secondly, a possible enteroenteral or enterohepatic recirculation of sulphate or sulphate-hydrogen sulphide-sulphate due to bacterial and human cell metabolism has not been quantified. Incorporation of blood sulphate into mucin is rapid ${ }^{59}$ and although quantitatively a minor route of sulphate excretion in this study, it may be important for the metabolism of mucin-degrading colonic bacteria.

Diet and intestinal absorption are the principal factors determining the size of the colonic sulphate pool in this study. Because the magnitude of this pool is likely to be a major determinant of sulphate reducing bacteria carriage and activity, it therefore follows that the epidemiology of human methanogenesis, which is inversely related to the carriage of sulphate reducing bacteria, ${ }^{5}$ should be determined at least in part by the quantity of sulphate ingested. There are no available data on sulphate intakes in human populations. We have, however, measured the sulphate in a composite rural African diet from a predominantly methanogenic population ${ }^{62}$ and found it to be only $2.7 \mathrm{mmol} /$ day (unpublished results), despite a large beer intake. By contrast, the high dietary sulphate consumed by the British population is associated with the carriage of significant sulphate reducing bacteria. Furthermore it is possible to stop methanogenesis in some subjects fed inorganic sulphate. ${ }^{7}$

We are indebted to Elaine Collard for help with the diets, and to the nursing staff and volunteers, without whose cheerful cooperation the study would not have been possible. TF is an Underwood Trust Fellow (British Digestive Foundation) and gratefully acknowledges support from the East Anglia Health Authority. Some of the results in this paper have been presented at the 1989 Medical Research Society meeting in Leeds.

1 Postgate JR. The sulphate-reducing bacteria. 2nd ed. Cambridge: Cambridge University Press, 1984.

2 Beerens $\mathrm{H}$, Romond C. Sulfate-reducing anaerobic bacteria in human faeces. Am f Clin Nutr 1977; 30: 1770-7.

3 Gibson GR, Macfarlane GT. Chemostat enrichment of sulphate-reducing bacteria from the large gut. Letters in Applied Microbiology 1988; 7: 127-33.

4 Florin THJ, Gibson GR, Neale G, Cummings JH. A role for sulphate-reducing bacteria in ulcerative colitis? Gastrosulphate-reducing bact

5 Gibson GR, Macfarlane GT, Cummings JH. Occurrence of sulphate-reducing bacteria in human faeces and the relationship of dissimilatory sulphate reduction to methanogenesis in the large gut. $\mathcal{F}$ Appl Bacteriol 1988; 65: 103-11.

6 Gibson GR, Cummings JH, Macfarlane GT. Use of a threestage continuous culture system to study the effect of mucin on dissimilatory sulfate reduction and methanogenesis by mixed populations of human gut bacteria. Appl Environ Microbiol 1988; 54: 2750-5.

7 Christl SU, Gibson GR, Florin THJ, Cummings JH. The role of dietary sulphate in methanogenesis in the human large intestine Gastroenterology 1990; A246.

8 Paul AA, Southate DAT. McCance and Widdowson's the composition of foods. 4th ed. London: HMSO, 1985.

9 The pharmacological basis of therapeutics. 5th ed. Goodman LS, The pharmacological basis of therapeutics. Sth ed. Good

10 Wilman A, eds. New York: Macmillan, 1975: 706. 1962: 134-7.

11 Turnberg LA, Bieberdorf FA, Morawski SG, Fordtran JS Interrelationships of chloride, bicarbonate, sodium and hydrogen transport in the human ileum. $\mathcal{F}$ Clin Invest 1970 49: 557-67.

$12 \mathrm{McNeil} \mathrm{NI}$, Cummings JH. Evidence for regional variations in large intestinal function. Gut 1979; 20: A439.

13 Sabry ZI, Shadarevian SB, Cowan JW, Campbell JA. Relationship of dietary intake of sulphur amino-acids to urinar excretion of inorganic sulphate in man. Nature 1965; 206: 331-3. 
14 Hele TS. Studies in the sulphur metabolism of the dog. 1. The synthesis of ethereal sulphate. Biochem f 1924; 18: 110-9.

15 Dziewatkowski DD. On the utilisation of exogenous sulphate by the rat. $\mathcal{F}$ Biol Chem 1949; 178: 389-93.

16 Dohlman C-H. The fate of the sulphate group of chondroitin sulphate after administration to rats. Acta Physiol Scand $1956 ; 37: 220-34$

17 Walser M, Seldin DW, Grollman A. An evaluation of radiosulphate for the determination of the volume of extracellular fluid in man and dogs. F Clin Invest 1952; 32: 292-311. 18 Bauer JH. Oral administration of radioactive sulphate to
measure extracellular fluid space in man. $\mathcal{F}$ Appl Physiol 1976; 40: 648-50.

19 Florin THJ, Goretski S, Neale G, Cummings JH. Sulphate in foods and beverages. Am f Clin Nutr (in press).

20. Bostrom H. Sulphate conjugation and sulphate conjugates. Scandinavian Society of Clinical Chemistry and Clinical Scandinavian Society of
Pathology 1965; 10: 33-52.

21 Huovinen JA, Gustaffson BE. Inorganic sulphate, sulphite and sulphide as sulphur donors in the biosynthesis of sulphur amino acids in germ-free and conventional rats. Biochim Biophys Acta 1967; 136: 441-7.

22 Turvey JR. Sulphates of the simple sugars. Advances in Carbohydrate Chemistry 1965; 20: 183-218.

23 Jørgenson BB. A comparison of methods for the quantification of bacterial sulphate reduction in coastal marine sediments. I. Measurement with radiotracer techniques. Geomicrobiology fournal 1978; 1: 11-28.

24 Bingham S. McNeil NI, Cummings JH. The diet of individuals: a study of a randomly chosen cross section of dividuals: a study of a randomly chosen cross section 45: 23-35.

25 Anonymous. Bread \& flour regulations. London: HMSO, 1984.

26 Hough JS, Briggs DE, Stevens R. Malting and brewing science. London: Chapman and Hall, 1978.

27 Ingles DL. Reactions of aldoses with bisulphite and hydrosulphite: the formation of sugar sulphates. Chemical Industry 1960; 6: 1159-60.

28 Thewlis BA, Wade P. An investigation into the fate of sulphites added to hard sweet biscuit doughs. Fournal of the Science of Food and Agriculture 1974; 25: 99-105.

29 Wedzicha BL. Review: chemistry of sulphur dioxide in vegetable dehydration. Int $\mathcal{F}$ Food Sci Tech 1987; 22: 433-50

30 Josefsson E. Glucosinolate content and amino acid composition of rapeseed meal as affected by sulphur and nitrogen nutrition. Fournal of the Science of Food and Agriculture 1970; 21: 891-903.

31 Ruppin H, Bar-Meir S, Soergal KH, Wood CM, Schmitt MG. Absorption of short chain fatty acids by the colon. Gastroenterology 1980; 78: 1500-7.

32 Deyrup IJ. In vitro transport of radiosulphate by the lower ileum of the rat. Fed Proc 1963; 22: 332-9.

33 Anast $C$, Kennedy $R$, Volk $G$, Adamson $L$. In vitro studies of sulphate transport by the small intestine of the rat, rabbit and hamster. F Lab Clin Med 1965; 65: 903-11.

34 Becker EL, Heinemann HO, Igarashi K, Hodler JE, Gershberg $H$. Renal mechanisms for the excretion of inorganic berg $H$. Renal mechanisms for the excretion of
sulphate in man. $\mathcal{F}$ Clin Invest $1960 ; 39$ : 1909-13.

35 Charkmakjian $\mathrm{ZH}$, Bethune JE. Sodium sulphate treatment of hypercalcemia. N Engl F Med 1966; 275: 862-9.

36 Brady CE, DiPalma JA, Morawski SG, Santa Ana CA Fordtran JS. Urinary excretion of polyethylene glycol 3350 and sulphate after gut lavage with a polyethylene glycol electrolyte lavage solution. Gastroenterologv 1986; 90: $1914-8$.
37 Chochetto DM, Levy G. Absorption of orally administered sodium sulphate in humans. F Pharm Sci 1981; 70: 331-3.

38 Chacko A, Cummings JH. Nitrogen losses from the human small bowel: obligatory losses and the effect of physical form of food. Gut 1988; 29: 809-15.

39 Lenter C, ed. Geigy scientific tables Vol I. Basle: Ciba-Geigy, 1981: $90-1$.

40 Macfarlane GT, Cummings JH, Macfarlane S, Gibson GR Influence of retention time on degradation of pancreatic enzymes by human colonic bacteria grown in a 3-stag continuous culture system. $\mathcal{F}$ Appl Bacteriol 1989; 67: 521-7.

41 Ramakrishna BS, Gee D, Weiss A, Pannall P, RobertsThomson IC, Roediger WEW. Estimation of phenolic conjugation by colonic mucosa. F Clin Pathol 1989; 42 620-3.

42 Binder $\mathrm{HJ}$; Ptak T. Jejunal absorption of water and electrolytes in inflammatory bowel disease. $7 \mathrm{Lab}$ Clin Med 1970 76: $915-24$.

43 LeVeen HH, Lyons A, Becker E. Physiological adaptation to ileostomy. Am ₹ Surg 1962; 103: 35-41.

44 Kennedy HI, Al-Dujaili EAS, Edwards CRW, Truelove SC. Water and electrolyte balance in subjects with a permanen ileostomy. Gut 1983; 24: 702-5.

45 Handbook of chemistry and physics. 57th ed. Weast RC, ed. Cleveland: CRC Press, 1976.

46 Dennis W, Reed L. The action of blood on sulphides. 7 Biol Chem 1927; 72: 385-94.

47 Bray AC. Sulphur metabolism in sheep. Australian fournal of Agriculture Research $1969 ; 20$ : 725-37.

48 Haggard HW. The fate of sulphides in the blood. 7 Biol Chem 1921; 49: 519-29.

49 Baxter CR, van Reen R, Pearson PR, Rosenberg C. Sulphide oxidation in rat tissues. Biochim Biophys Acta 1958;27: 581-91.

50 Curtis CG, Bartholomew TC, Rose FA, Dodgson KS. Detoxification of sodium 35S-sulphide in the rat. Biochem Pharmacol 1972; 21: 2313-21.

51 Koj A, Frendo J, Janik Z. [35S] Thiosulphate oxidation by rat liver mitochondria in the presence of glutathione. Biochem $f$ 1967; 103: 791-5.

52 Sorbo B. On the mechanism of sulphide oxidation in biological systems. Biochim Biophys Acta 1960; 38: 349-51.

53 Wheldrake JF, Pasternak CA. The control of sulphate activation in bacteria. Biochem $\mathcal{F}$ 1965; 96: 276-80.

54 Kredich NM. Regulation of I-cysteine biosynthesis in Salmonella typhimurium. F Biol Chem 1971; 246: 3474-84.

55 Stephen AM, Cummings JH. The microbial contribution to human faecal mass. $\mathcal{f}$ Med Microbiol 1980; 13: 45-56.

56 Wesley A, Forstner J, Quereshi R, Mantle M, Forstner G. Pediatr Res 1983; 17: 65-9.

57 Stephen AM, Haddad AC, Phillips SF. Passage of carbohydrate into the colon. Gastroenterology 1983; 85: 589-95.

58 Englyst HN, Cummings JC. Digestion of the carbohvdrates of banana in the human small intestine. Am f Clin Nutr 1986: 44: 42-50.

59 Jennings MA, Florey $\mathrm{H}$. Autoradiographic observations on the mucous cells of the stomach and intestine. $Q \mathcal{F} E x p$ Physiol 1956; 41: 131-51.

60 Liau YH, Horowitz MI. The importance of PAPS in determining sulphation in gastrointestinal mucosa. Digestion 1976; 14: $372-5$.

61 Filipe MI. Mucins in the human gastroepithelium: a review. Invest Cell Pathol 1979; 2: 195-216.

62 Segal I, Walker ARP, Lord S, Cummings JH. Breath methane and large bowel cancer risk in contrasting African populations. Gut 1988; 29: 608-13. 